\title{
The studies of the cooperation model of Yunnan and neighboring countries in the restructuring of production capacity
}

\author{
Xianmin Zeng \\ International Business School \\ Yunnan University of Finance and Business \\ Kunming,China \\ 836097550@qq.com
}

\author{
Ersi Liu* \\ International Business School \\ Yunnan University of Finance and Business \\ Kunming,China \\ Liuersi309@126.com
}

\begin{abstract}
Yunnan is located in the southwest corner of China, bordering Myanmar, Laos and Vietnam.The unique geographical location and cultural environment make Yunnan the role of "important land channel" and "important strategic pivot" in the "One Belt And One Road" strategy. Yunnan province in recent years has been in constant development, and constantly upgrade the industrial structure optimization, but in the process of industrial upgrading there are still some problems, such as excess capacity, etc. Based on the One Belt And One Road strategic background, this paper studies the problem of structural adjustment of production capacity and how to cooperate with neighboring countries in Yunnan. In Yunnan province, Myanmar, Laos and Vietnam cooperation in the field of the status and outlook of different industries, related how to adjust production capacity in Yunnan province were analyzed, and provides the conclusion and basis for the production structure adjustment of Yunnan province.
\end{abstract}

Keywords-capacity structure; cooperation; industrial restructuring; international cooperation

\section{INTRODUCTION}

September and October, 2013, Chinese President Jinping $\mathrm{Xi}$, during a visit to central Asia and southeast Asia countries, successively put forward to build economic belt "silk road" and "maritime silk road in the 21st century" (hereinafter referred to as the "One Belt And One Road") the major initiative, attention to international society. Yunnan location advantages, can promote international transport corridor construction with its neighboring countries, a new heights, and the greater Mekong sub-regional economic cooperation construction be geared to the needs of the radiation center of the South Asia, southeast Asia.The "One Belt And One Road" strategy has provided a valuable opportunity for the development of Yunnan in the new historical starting point.

A. At present, there is a lot of researches done by domestic scholars on the issue of production capacity cooperation under the background of "One Belt And One Road"

Security,environmental level, economic and policy and investment environment level that should improve from the efficient communication system to enhance their quality of the enterprise, strengthen the related fields of think tanks such as

\footnotetext{
* Corresponding author
}

the construction of ideas and strategies to cope with.Huaiqin $\mathrm{Mu}$, Jun Wang (2016) [3] believes that international cooperation should take the path capacity as the key developing countries, the key industries of international cooperation, textile and other automobile production capacity, the implementation of the classification, promoting the development of good policy support and consultation services, good environmental and ecological protection work, to improve government administrative work efficiency, financial innovation and entrepreneurship level.Chen Jiyong, Jiang Yanping, Baoshuang Wang (2017) [4] argued that China's participation in the path of the international cooperation capacity to foreign direct investment as the carrier, strengthen exchanges and cooperation of China and related industries. Based on trade development, the market potential of "One Belt And One Road" is dug deep.Dongqi Zhao,Baichuan Sang (2016) [1] based on the viewpoint of industrial international competitiveness of the empirical analysis that strong capacity "The Belt and Road" initiative should rely on China's manufacturing industry, give full play to the initiative; make full use of our country and South Asia and Southeast Asia trade complementary strong features, trade potential. In the manufacturing sector to" go out "at the same time, the implementation of other departments" bringing in "strategic; strengthen China and West Asia and the CIS region trade relations, in order to solve the problem of China's high dependence on fossil fuels and other resource products, to ensure the stable supply of energy.Qianqian Zuo (2013) studies the influence factors of China's regional economic development from the aspect of political factors.

\section{B. Study on the industrial structure of Yunnan Province}

Jianhong Niu (2016) [7] in Yunnan national pharmaceutical industry as an example, consider the strategy for Southeast Asia radiation center should be based on national medicine as the construction of the bridge and the link of the radiation of South Asia and Southeast Asian countries.Dandan Zhang, Kun Chen (2015) [9] from the perspective of new economic norm transformation and upgrading of industrial structure,pointed out the problem of slow, industry technological innovation capability is weak labor quality, should consider the optimization of the industrial structure to resolve the overcapacity and reasonable 
utilization of Yunnan province's own resources.Anjun Tao, Wei Sun (2010) [10] considered as a frontier of China and ASEAN cooperation, Guangxi, Yunnan, Vietnam, the three party due to the development stage of the formation of approximation, greater competition and cooperation in the overall situation.

\section{Researches on the structure of property rights}

Liguo Wang, Lei Wang (2014) [5] by SSCP analysis of the influencing factors of Chinese industrial performance paradigm analysis at this stage, the structure of property rights is one of the most important factors that to resolve the current overcapacity contradiction fundamentally.

This paper aims at the background of "The Belt and The Road'Initiative strategy based on capacity structure adjustment of Yunnan Province, how to carry out cooperation with neighboring countries. In Yunnan province and the status of Vietnam, Burma and Laos and the prospect of cooperation in the field of different industries in Yunnan Province, how to adjust the capacity analysis, and provide basis for the conclusion of Yunnan province production structure adjustment.

\section{The PRESENT SituAtion OF INDUSTRIAL StRUCTURE IN YunNAN PROVINCE AND THE PROBLEMS EXISTING IN THE ADJUSTMENT OF PRODUCTION CAPACITY}

\section{A. The present situation of industrial structure in Yunnan}

According to figure from Yunnan Provincial Bureau of Statistic ,the total revenue of the whole year was 3250.02 billion yuan, an increase of $3.0 \%$ over the previous year. The provincial public general budget revenue was 180814 billion yuan, up 6.5 percent from the previous year. The value-added tax was 190.25 billion yuan, up $2.2 \%$. The sales tax was 36768 million yuan, down $7.2 \%$. The enterprise income tax reached
14744 million yuan, down 7.6 percent. Complete province local public budget of 471.29 billion yuan, an increase of $6.2 \%$ over the previous year, among them, the spending on social security and employment, health care and family planning spending, following spending, housing security and education spending growth of $11.0 \%, 20.0 \%, 8.0 \%, 11.0 \%$ and $13.7 \%$.

Fig. 1. 2010-2015 Yunan Tatal Industrial added Value and Growth Rate

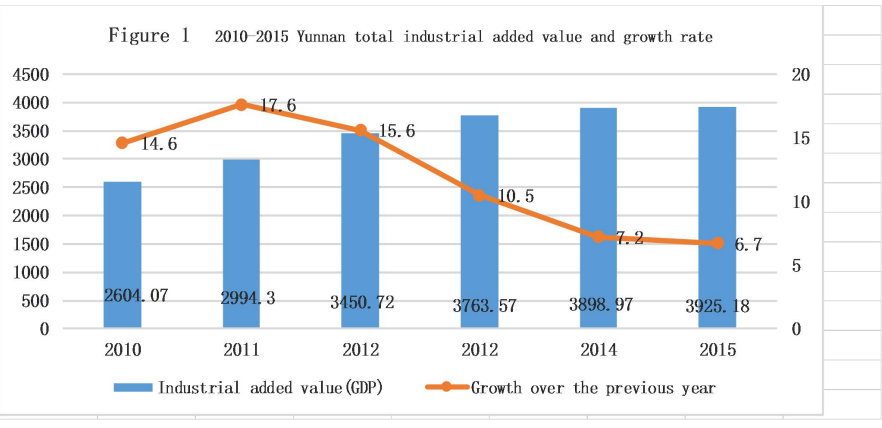

(data from the Yunnan Provincial Bureau of Statistics)

Steady growth of industrial production.According to Figure1, the annual total industrial added value of 392 billion 518 million yuan, an increase of $6.7 \%$ over the previous year. Above scale industrial added value of 362 billion 308 million yuan, an increase of $6.7 \%$. In the above scale industry, the economic type, the state-owned and state holding enterprises grew by $6.4 \%$, collective enterprises increased by $7.6 \%$, jointstock enterprises grew by $6.3 \%$, the private sector grew by $9.2 \%$. Sub sectors, the mining industry added value of 32 billion 669 million yuan, an increase of $10.6 \%$; manufacturing added value of $\$ 273$ billion 198 million, an increase of $6 \%$; electricity, heat, gas and water production and supply industry added value of 56 billion 441 million yuan, an increase of $7.5 \%$.

TABLE I. GROSS DOMESTIC PRODUCT BY TERTIARY INDUSTRIES
Gross domestic product by tertiary industries (2016)

\begin{tabular}{|c|c|c|c|c|c|c|c|c|c|c|c|}
\hline \multirow{2}{*}{\multicolumn{2}{|c|}{ Region }} & \multirow[b]{2}{*}{ GRDP } & \multicolumn{3}{|c|}{ Tertiary industrial added value } & \multicolumn{3}{|c|}{ Composition (GRDP $=100)$} & \multicolumn{3}{|c|}{ Index (last year $=100$ ) } \\
\hline & & & $\begin{array}{l}\text { Primary } \\
\text { industry }\end{array}$ & $\begin{array}{c}\text { Secondary } \\
\text { industry }\end{array}$ & $\begin{array}{l}\text { Tertiary } \\
\text { industry }\end{array}$ & $\begin{array}{l}\text { Primary } \\
\text { industry }\end{array}$ & $\begin{array}{c}\text { Secondary } \\
\text { industry }\end{array}$ & $\begin{array}{l}\text { Tertiary } \\
\text { industry }\end{array}$ & $\begin{array}{l}\text { Primary } \\
\text { industry }\end{array}$ & $\begin{array}{c}\text { Secondary } \\
\text { industry }\end{array}$ & $\begin{array}{c}\text { Tertiary } \\
\text { industry }\end{array}$ \\
\hline \multirow{6}{*}{$\begin{array}{c}\text { Easter } \\
\mathbf{n} \\
\text { seabo } \\
\text { ard }\end{array}$} & Shandong & 63002.33 & 4979.08 & 29485.90 & 28537.35 & 7.9 & 46.8 & 45.3 & 108.0 & 104.2 & 107.4 \\
\hline & Jiangsu & 70116.38 & 3986.05 & 32044.45 & 34085.88 & 5.7 & 45.7 & 48.6 & 108.5 & 103.3 & 108.3 \\
\hline & Shanghai & 25123.45 & 109.82 & 7991.00 & 17022.63 & 0.4 & 31.8 & 67.8 & 106.9 & 86.4 & 101.2 \\
\hline & $\begin{array}{c}\text { Zhe } \\
\text { jiang }\end{array}$ & 42886.49 & 1832.91 & 19711.67 & 21341.91 & 4.3 & 46.0 & 49.8 & 108.0 & 101.5 & 105.3 \\
\hline & $\begin{array}{c}F u \\
\text { jian }\end{array}$ & 25979.82 & 2118.10 & 13064.82 & 10796.90 & 8.2 & 50.3 & 41.6 & 109.0 & 103.7 & 107.4 \\
\hline & Guangdong & 72812.55 & 3345.54 & 32613.54 & 36853.47 & 4.6 & 44.8 & 50.6 & 108.0 & 103.3 & 107.0 \\
\hline \multicolumn{2}{|c|}{ Yunnan } & 13619.17 & 2055.78 & 5416.12 & 6147.27 & 15.1 & 39.8 & 45.1 & 108.7 & 105.9 & 108.6 \\
\hline
\end{tabular}

2010-2016, the industrial structure of Yunnan province has been constantly optimized and upgraded, but there are still irrational structure, which seriously hindered the healthy and stable development of Yunnan's economy.From the above data we can see the gap of the industrial structure between Yunnan province and the eastern coastal provinces.Although in 2016, the industrial structure of Yunnan province has reached a good optimization effect, but the gap between the eastern coastal provinces is still large.

\section{B. Problems existing in the structural adjustment of production capacity in Yunnan}

1) Excess capacity.

Most of the current overcapacity in the industry focused on raw materials manufacturing enterprises.Excess capacity, 
in accordance with the definition of current industry, which refers to the whole society or a given area can be produced under construction equipment, production equipment, a period of time for the construction of production equipment, they added capacity and, when the capacity is greater than the sum of the current social demand, this situation is called overcapacity.The excess capacity will bring a lot of problems; product prices fell sharply; product inventory increased; financial risks; trade friction; waste of resources, pollution of the environment; affect employment and social stability.In the first half of 2014, Yunnan's GDP grew by $8.4 \%$, industrial added value increased by $8 \%$, compared with the same period in 2013 fell by $4 \%$ and $5.6 \%$. The growth decline can be inferred is not up to the optimal capacity problems, mainly industrial prices slump and enterprise efficiency decline or even loss of production and management, difficult to continue the economic downward pressure increasing, this is the lack of effective demand leads to the negative impact of overcapacity.Therefore, in order to solve excess capacity, increase effective demand, Yunnan and neighboring countries to carry out capacity cooperation is very necessary.Through capacity cooperation and capacity output, in Yunnan and neighboring countries resources and complementary advantages, to better solve the problem of excess capacity.

\section{2) Backward production capacity}

Backward production capacity is a technical judgment, overcapacity is a market judgment.Backward production capacity and excess capacity is not completely separated, either this or that.In the perfect market economy conditions, the excess capacity generally includes backward production capacity, while the elimination of backward production capacity, exit can change the market supply and demand, reduce the degree of excess capacity.In the practice of the elimination of backward production capacity of the local government in Yunnan Province, the implementation of the policy can be divided into restrictive policies, encouraging policies and mandatory policies.Restriction policy is mainly the production of access (approval and permission) policies, restrictive policies production conditions (fuel, water, transportation, finance, land), technology (energy

consumption, safety and quality standards) policy, environmental emissions restriction policy;Incentive policies are mainly tax incentives, financial incentives to reward incentives;The mandatory elimination policy include environmental protection, quality, safety, and law enforcement policies Strong push in the elimination of backward production capacity requirements of the government under the interaction of various policies, formed a relatively complete system of policies and measures to eliminate backward production capacity.Supply side structural reforms in Yunnan is to from improving supply quality, promote structural adjustment by way of reform, the correction factor allocation distortion, expand the effective supply, improve the supply structure of the changing needs of adaptability and flexibility, improve the total factor productivity, to better meet the needs of the masses, and promote sustained and healthy economic and social development.China and neighboring countries are developing countries, there is still a lot of development space in some areas of technology.Backward production capacity is also an obstacle to the development of Yunnan and neighboring countries.In terms of backward production capacity, Yunnan can also cooperate with neighboring countries, technical improvement and reform, eliminate backward production capacity.

\section{3) Export shortage}

The export commodities structure and varieties of Yunnan,which trade with the surrounding countries, are relatively unitary.The export products of Yunnan province are mainly concentrated in the low added value of mechanical products, batteries, textiles and Puer tea, as well as the relative saturation of the market capacity.Light industry and deep processing products export ratio is very small.And in Yunnan province and the surrounding countries in the field of hightech cooperation,technology content is low, influence the effect of trade and level, and the difficulty of economic integration have increased.

\section{ThE STATUS AND DifFICUlTIES OF PRODUCTION CAPACITY COOPERATION BETWEEN YUNNAN AND NEIGHBORING COUNTRIES(VIETNAM,MYANMAR,LAOS)} Table II. The total Trade Value of YunNan and AsEan

\begin{tabular}{|c|c|c|c|c|c|c|c|c|}
\hline \multirow[b]{2}{*}{ Country (region) } & \multirow{2}{*}{$\begin{array}{l}\text { Import and } \\
\text { export }\end{array}$} & \multirow[b]{2}{*}{ Proportion\% } & \multirow[b]{2}{*}{ Export } & \multirow[b]{2}{*}{ Export } & \multirow[b]{2}{*}{ Balance of trade } & \multicolumn{3}{|c|}{ on year-on-year basis\% } \\
\hline & & & & & & $\begin{array}{c}\text { Import and } \\
\text { export }\end{array}$ & Export & Import \\
\hline ASEAN total & 291060 & 100.0 & 218295 & 72765 & 145530 & 0.4 & 31.6 & -41.4 \\
\hline Myanmar & 106554 & 36.6 & 46930 & 59624 & -12694 & -24.3 & -42.9 & 1.7 \\
\hline Laos & 16549 & 5.7 & 10423 & 6126 & 4297 & -65.8 & -69.5 & -56.6 \\
\hline Vietnam & 27654 & 9.5 & 25405 & 2249 & 23156 & 58.2 & 87.8 & -43.1 \\
\hline
\end{tabular}

\section{A. Cooperation status}

\section{1) Cooperation between Yunnan and Vietnam}

From the Table II we can see that the amount of import and export trade between Yunnan and Vietnam is \$276 million 540 thousand, exports grew by $87.8 \%$, imports fell by $43.1 \%$, the trade balance reached $\$ 231$ million 560 thousand. In 2007, Yunnan proposed the planning and construction of the estuary of China - Vietnam Lao Street Cross Border Economic Cooperation Zone.2015, the two sides reached a consensus on the issue of Sino Vietnamese joint communique, China and Vietnam will promote the implementation of the list of key cooperation projects and bilateral economic and trade cooperation agreements have been signed.

\section{2) Cooperation between Yunnan and Myanmar}

The Table II shows that the import and export trade between Yunnan and Myanmar was \$1.06654 billion, exports fell by $42.9 \%$ year on year, imports rose by more than the same period last year, the balance of trade reached $\$ 126.94$ 
million.In 2017,to further promote the China-Myanmar border trade,China has proposed to Myanmar, the construction of Ruili-Myanmar the cross-border economic cooperation zone.

\section{3) Cooperation between Yunnan and Laos}

From the table we can see that the amount of import and export trade between Yunnan and Laos is $\$ 165.49$ million,exports fell by $69.5 \%$ year on year, imports fell by $56.6 \%$, the trade balance reached \$42.97million.Investment by Yunnan Province Construction Investment Holding Group Co. Ltd.,Laos Saysettha comprehensive development zone projects progressing smoothly.

\section{B. The facing problems}

\section{1) The transportation problems}

Yunnan and the surrounding countries are complex terrain, the construction of transport infrastructure is relatively backward, there is no complete transport network.Railway network coverage is not comprehensive, and because Yunnan is in the mountain plateau, highway transportation is not convenient and safe. Yunnan and neighboring countries can only rely on land transport, air transport and pipeline transportation.At present, the highway and railway construction in Yunnan province has become an important project of national development and construction.

\section{2) The cost problems}

Because of transportation restrictions, sea transportation cannot be chosen.Air transport is fast and convenient, but it's very expensive.Yunnan's railway is still under construction, highway transportation cost is reasonable,because of the terrain, the safety cost of highway transportation also needs to be considered.The construction cost and maintenance cost of pipeline transportation are high.Moreover, the cooperation between Yunnan and neighboring countries requires a large number of professionals, in recent years, China's rising cost of talent, the talent costs are also a high cost.

\section{3) The financial problems}

The development of a region needs a lot of financial support, Yunnan province has great potential for development, the country's financial support is far less than the development needs of Yunnan Province.Yunnan and neighboring countries have less investment in science, technology and education, lack of funds for research and development and personnel training, and lack of advanced scientific research equipment and means, as well as high-tech research and application personnel.As Yunnan is in less developed areas in China, the financial support is far less than that of the eastern coastal areas.And cross-border economic cooperation zone infrastructure construction funds demand is large, Vietnam, China and Laos and Myanmar cooperation mechanism has not been established.Large funding gap and capital bottleneck problem has not been resolved.

\section{4) The industrial technical problems}

The industry of Yunnan Province is in a relatively backward position in the whole country, and industrial technology restricts the development of Yunnan's industry.Neighboring countries are also developing countries,and there is no strong industrial system as a support for development.Although it has the advantage in the resource endowment, the backward technology of the technology has not made full use of its natural advantages and resources. At present, Yunnan's industrial technology is not mature, some industries are at a low level, relying on resources, and lack of the development in high-tech industries. With the rapid development of economy in Yunnan Province and neighboring countries, as well as countries or regions to speed up the transformation of growth mode from extensive management to intensive management, more and more demand for science and technology is put forward.

\section{5) The market problems}

Market is an important guarantee for regional economic and trade cooperation and development.Vietnam, Laos and Myanmar have a relatively low level of financial development and have not yet formed a complete financial service system. Market access environment is not very good, such as tariffs, non-tariff barriers, commodity trade discriminatory treatment,and there are many problems of transnational regional investment environment in Yunnan Province and neighboring countries.

\section{6) The political problems}

Political stability is the prerequisite for development.China and Myanmar, Vietnam had a trade dispute, and there have been acts of boycott of Chinese goods. This is detrimental to the long-term friendly cooperation and development between China and Vietnam. There are still some hidden dangers in the political instability:Some areas of investment policies and regulations are still have discriminatory treatment; investment in the field of fair competition still needs further construction. Stable political situation can provide a good prerequisite for the development of Yunnan Province and neighboring countries.

\section{YunNAN PRovince AND NEIGHBoring COUNTRIES (VIETNAM, BURMA, LAOS) COOPERATION MODEL CHOICE ON THE STRUCTURAL AdJUSTMENT OF PRODUCTION CAPACITY}

\section{A. Resource Advantages}

Vietnam has a common border with the He Kou in HaniYi Autonomous Prefecture of Honghe.Vietnam is rich in water resources and has a unique natural conditions for the construction of water resources.Burma is in the southwest of China,and has a common border with Dai Autonomous Prefecture of Sipsongpanna,Puer City,Lincang City,Dehong Autonomous Prefecture and Nujiang of the Lisu Autonomous Prefecture.Burma is rich in oil, gas, water, agriculture, forestry, marine fisheries, labor and other resource and so is Laos.Laos is a landlocked country, with the completion of the opening of the old railway,it will further increase the cooperation and contact between Yunnan Province and Laos.

\section{B. Capacity Cooperation Model}

- Building a two-way industrial chain through the Internalization Model.Yunnan Province forms the internalization of the market with its neighboring countries through internal organization system with lower cost,and can use management means to coordinate internal resources of the neighboring 
countries of Yunnan and configuration to avoid the impact of incomplete market on business efficiency.Yunnan Province is the main output of electricity to neighboring countries, and it also needs to import electricity from neighboring countries.This geographical advantage can be used to build hydropower to ensure Vietnam's electricity input to Yunnan Province.Build a two-way industry chain cooperation, reduce the cost of production cooperation with surrounding countries in Yunnan Province,and it is conducive to emergence and development of enterprises in Yunnan Province and its neighboring countries.It is also helpful for Yunnan Province and its neighboring countries to build "regional brand" and promote the development of regional economy.

- Through the "enclave economy" model to build the industrial processing zones.Yunnan Province and the neighboring countries can adopt the dual-share investment model and share the infrastructure investment with each other in accordance with the agreement.In accordance with the management style of the two countries, the mechanism of long-term friendly cooperation between the two sides should be established, and the Base Management Committee shall be jointly stationed by both parties.Relying on China-Myanmar oil and gas pipeline project, Yunnan Province can accelerate the development of petrochemical deep processing industry chain and the completion of the industrial chain of the new oil refining and petrochemical base. Laos and Vietnam have abundant water resources, Yunnan Province and Laos can cooperate in the production structure adjustment, by vigorously using abundant water resources, making the capacity structure of Yunnan Province to the new energy and environmental protection type adjust the direction of development, to innovation driven shift from resource consumption.

- Through cross-border cooperation zone model to build capacity coordination mechanism, Yunnan Province actively build cross-border cooperation with neighboring countries to strengthen regional and industry capacity coordination.Yunnan solar thermal utilization, new energy and other fields of science and technology in the domestic take the leading position, and there is a huge market demand among the ASEAN countries in the new energy technologies, products.Iron and steel, coal and other industries in Yunnan Province are overcapacity, the output of excess capacity in Yunnan Province is to solve the industry overcapacity, it also has output to neighboring countries to achieve cooperation, achieve a win-win situation.We will strengthen technological upgrading in the process of output and transfer, reduce pollution and make environmental protection facilities in cross-border cooperation zones. We should set up a standard for input in production capacity, set up a protection environment for environmental protection, and integrate all the capacity units and increase capacity utilization in the progress of building cross-border cooperation zones.
By Appropriately enhancing the management of some of the capacity of the construction of co-ordination functions to achieve a reasonable allocation of capacity units between regions, and continuously improve the overall level of the industry's total production capacity.

- Through mergers and acquisitions, restructuring, FDI and other models to increase technical and economic cooperation.In recent years, Yunnan Province emerging industries with new energy, new materials, advanced equipment manufacturing and electronic are developing constantly, the development and changes in Yunnan Province attract more cooperation with neighboring countries, so as to improve their own economy and accelerate the rapid development of national economy.Therefore, the large market demand, strong market advantage, common development goals making Yunnan Province and neighboring countries achieve common development through complementary advantages.Some capacity companies in Yunnan Province and neighboring countries can cooperate on production capacity through mergers and acquisitions and reorganizations to complement each other. In the pattern of FDI to increase technical and economic cooperation, Yunnan Province can provide technical support for the neighboring countries, the neighboring countries can provide strong guarantee and conditionsto Yunnan Province conversely in terms of capacity.

\section{Industry Cooperation Distribution}

Relying on natural conditions to carry out cooperation projects.China has direct road traffic lines in countries such as Vietnam, Myanmar and Laos, and it is also very convenient for water transportation in the greater Mekong region.Yunnan Province and neighboring countries should make use of the existing basis to strengthen the interconnection between Yunnan Province and neighboring countries and vigorously promote the Yunnan Province and neighboring countries in highway, railway, waterway, aviation, information communication and networking.In the process of carrying out the construction of infrastructure, the government can consider the introduction of PPP (Public-Private-Partnership, a publicprivate partnership) financing model to promote the building of traffic (highway, railway, airport, port), health (hospital), education (schools), the construction of public property management project. Reasonably use of PPP financing model, on one hand, can reduce the government's financial pressure, on the other hand can also make private capital profitable, the government and private capital can form a long-term goal of mutual benefit.

\section{Supporting policies}

Implement the basic role of market system in resource allocation.In order to strengthen the industrial cooperation between Yunnan Province and neighboring countries and the level of common development, the two sides should further reduce tariff and non-tariff barriers. Making full use of market mechanisms in these countries within the resource allocation function, and making all kinds of enterprises can fully enjoy the benefits from liberalization of trade and investment facilitation,and promoting the rational allocation of industry 
resources in the area without being limited by policy. The government should transform their roles in the "referee" and "guide", rather than participate in the game players, as far as possible to open the market and create convenient financing channel for social capital and enterprise,and provide a more convenient investment environment for further industrial cooperation between Yunnan Province and neighboring countries.

Establish and improve emergency response mechanisms and formulate emergency plans for all contingencies that may occur within the region.As part of Southeast Asia and South Asia countries have certain political instability, international territorial disputes triggered by the domestic unrest situation may have a great impact or negative impact on industrial cooperation.Once the industrial cooperation in a variety of unexpected events, the government need to start the emergency plan in a timely manner and reduce the possible losses due to unexpected events. When making the emergency plans, priority should be given to how to protect the staff's personal and capitals like plant industries such as fixed assets, it can avoid the huge losses of confidence in the industry cooperation due to frequent incidents.

\section{ACKNOWLEDGMENT}

I would like to express my sincere gratitude to my supervisor,Professor Liu,for his instructive advice and useful suggestions. I am deeply grateful of his help in the completion of this thesis.

\section{REFERENCES}

[1] Q.Z. Dong, and S.C. Bai, "International Capacity Cooperation on "One Belt And One Road"-Based on the Empirical Analysis of International Competitiveness," International Trade Journal, vol. 10, 2016, pp. 4-14.

[2] M.C. He, and B. Tian, "Difficulties in Implementing the "Belt and Road" Strategy and the Solutions - Based on Field Investigations in Countries in Central Asia, West Asia, South Asia, Southeast Asia, and Central and Eastern Europe," Frontiers, pp. 55-62, March 2016.
[3] H.Q. Mu, and J.Wang, "On the path of international cooperation capacity under"The Belt and Road" strategic framework," People's Tribune, pp. 87-89, March 2016.

[4] J.Y. Chen, Y.P. Jiang, and B.S. Wang, "The Belt and Road" Strategy and China's participation in international capacity cooperation," Learn and Practice, 2017, pp. 5-12.

[5] L.G. Wang, and L. Wang, "Ownership Structure Local Government Intervention And Overcapacity-Based on SSCP Paradigm Analysis about China Industrial Economic Performance," Research on Economics and Management, vol. 7, 2014, pp. 65-73.

[6] X.L. Xia, “"The Belt and Road"international production cooperation mechanism and policy system,"China Business Update, 2015, pp. 26-33.

[7] J.H. Niu, "Opportunity and challenge: a strategy based on the radiation center in South Asia and Southeast Asia: a case study of Yunnan national pharmaceutical industry," Research on Development, 2016, pp. 123-127.

[8] B.T. Tian, and X.W. Wang, "LI Juan,Industrial Structure Level Assessment of Yunnan Province by Shift-Share Method," Journal of Subtropical Resources and Environment, pp. 76-82, March 2013.

[9] D.D. Zhang, and K. Chen, "Research on the path of industrial structure transformation and upgrading in Yunnan under the new normal," Economic Vision, vol. 9, 2015, pp. 60-64

[10] A.J. Tao, W. SUN, "The Impacts Of China- ASEAN Free Trade Area On Regional Development Pattern Of China Ana China' s Adaptive Strategies," Economic Geography, pp. 705-710, May 2010.

[11] Y. Li, and F.Yang, "Analysis of New Path of Energy Supply - side eform under the New Normal of Chinese Economy:Based on the Perspective of Capacity,Structure and Energy Consumption Patterns," Economic Question, 2016, pp. 1-6.

[12] J. Guo, T. Fu, and Q. Yang, "Influencing Factors and Countermeasures of Industrial Structure Transform and Upgrading In Ethnic Minority Regions of Western China---Taking Yunnan Province as Example," Journal Of Graduate School Of Chinese Academy Of Social Science, pp 57-61, March 2015.

[13] D.Z. Ying, "Study on the elimination of backward production capacity by Yunnan provincial government," Master degree thesis of Yunnan University of Finance and Economics, 2013.

[14] Q.L. Song, "The Current Situation, Problems and Countermeasures Of Trade Facilitation Between Yunnan and Neighboring Countries Under the New Round of Border Opening," Master degree thesis of Yunnan University of Finance and Economics, 2013.

[15] Q.Q. Zuo, "Coordinated Regional Economic Development Study in the Perspective of Marxist Theory of Political and Economic Relations," Master degree thesis of Xi'an University of Science and Technology. 